\title{
Both Isocarbohydrate and Hypercarbohydrate Fruit Preloads Curbed Postprandial Glycemic Excursion in Healthy Subjects
}

\author{
Xuejiao Lu ${ }^{1}$, Jiacan Lu ${ }^{1}$, Zhihong Fan ${ }^{1,2, * \mathbb{C}}$, Anshu Liu ${ }^{1}$, Wenqi Zhao ${ }^{1}$, Yixue $\mathrm{Wu}^{1}$ and Ruixin Zhu ${ }^{1}$ \\ 1 College of Food Science and Nutritional Engineering, China Agricultural University, Beijing 100083, China; \\ feirlu@163.com (X.L.); jiacanlu0613@163.com (J.L.); liuanshu@cau.edu.cn (A.L.); \\ zhaowenqi@cau.edu.cn (W.Z.); xiaoc0105@126.com (Y.W.); zhuruixin07@126.com (R.Z.) \\ 2 Key Laboratory of Precision Nutrition and Food Quality, Department of Nutrition and Health, \\ China Agricultural University, Beijing 100083, China \\ * Correspondence: daisyfan@cau.edu.cn; Tel.: +86-10-62737717
}

Citation: Lu, X.; Lu, J.; Fan, Z.; Liu, A.; Zhao, W.; Wu, Y.; Zhu, R. Both Isocarbohydrate and Hypercarbohydrate Fruit Preloads Curbed Postprandial Glycemic Excursion in Healthy Subjects. Nutrients 2021, 13, 2470. https:// doi.org/10.3390/nu13072470

Academic Editor: Paul Holvoet

Received: 29 June 2021

Accepted: 13 July 2021

Published: 19 July 2021

Publisher's Note: MDPI stays neutral with regard to jurisdictional claims in published maps and institutional affiliations.

Copyright: (c) 2021 by the authors. Licensee MDPI, Basel, Switzerland. This article is an open access article distributed under the terms and conditions of the Creative Commons Attribution (CC BY) license (https:// creativecommons.org/licenses/by/ $4.0 /)$.

\begin{abstract}
This study aimed to investigate the impact of fruit preloads on the acute postprandial glycemic response (PGR) and satiety response of a rice meal in healthy female subjects based on iso-carbohydrate (IC) and hyper-carbohydrate (HC) contents, respectively. The IC test meals including (1) rice preload $(R+35 R)$, (2) orange preload $(O+35 R)$, (3) apple preload $(A+35 R)$ and (4) pear preload $(\mathrm{P}+35 \mathrm{R})$, contained $50.0 \mathrm{~g}$ available carbohydrates $(\mathrm{AC})$ where the preload contributed $15.0 \mathrm{~g}$ and rice provided $35.0 \mathrm{~g}$. The $\mathrm{HC}$ meals included (1) orange preload $(\mathrm{O}+50 \mathrm{R}),(2)$ apple preload $(\mathrm{A}+50 \mathrm{R})$ and $(3)$ pear preload $(\mathrm{P}+50 \mathrm{R})$, each containing $65.0 \mathrm{~g} \mathrm{AC}$, where the fruits contributed $15.0 \mathrm{~g}$ and rice provided $50.0 \mathrm{~g}$. Drinking water $30 \mathrm{~min}$ before the rice meal was taken as reference $(\mathrm{W}+50 \mathrm{R})$. All the preload treatments, irrespective of IC or HC meals, resulted in remarkable reduction $(p<0.001)$ in terms of incremental peak glucose (IPG) and the maximum amplitude of glycemic excursion in $180 \mathrm{~min}\left(\mathrm{MAGE}_{0-180}\right)$, also a significant decrease $(p<0.05)$ in the area of PGR contributed by per gram of AC (AAC), compared with the $W+50 R$. Apple elicited the lowest PGR among all test meals, as the $A+35 R$ halved the IPG and slashed the incremental area under the curve in 180 min (iAUC ${ }_{0-180}$ ) by $45.7 \%$, while the A + 50R reduced the IPG by $29.7 \%$, compared with the $W+50 R$. All the preload meals and the reference meal showed comparable self-reported satiety in spite of the difference in AC. In conclusion, pre-meal consumption of three fruits effectively curbed post-meal glycemia even in the case of a $30 \%$ extra carbohydrate load.
\end{abstract}

Keywords: glycemic response; preload; fruit; apple; satiety

\section{Introduction}

White rice, a high glycemic index (GI) food [1,2], is the most popular staple food in Asian cultures. Daily intake of high GI staple foods such as white rice may lead to large postprandial glycemic fluctuation [3] even in healthy people [4]. Results from several metaanalyses suggested that a positive association between the consumption of white rice and the prevalence of type 2 diabetes [5,6].

Increasing evidence indicated that some macronutrients preload could stabilize postprandial glycemic response (PGR) and improve HbA1c in long-term treatments [7-11]. Whey protein preload could blunt the postprandial glucose excursion partly by enhancing the insulin response and slowing gastric emptying $[8,12,13]$. However, a few studies suggested that pre-meal consumed carbohydrates exerted a hypoglycemic effect as well, such as small doses of fructose [14], glucose [15] and mixed glucose-fructose solution [16].

The World Health Organization (WHO) called for a limitation of free sugar [17], as the consumption of refined sugar would result in a reduction of nutrient density, especially the excessive consumption of fructose from the sugar-sweetened beverages concerning a series of adverse health outcomes [18-20]. However, the sugar in a reasonable amount of fruit is 
not a concern, as fruit consumption increases the intake of phytochemicals, potassium and dietary fiber, which are beneficial to the prevention of cardiovascular diseases [21-23].

Moreover, increasing epidemiological studies and meta-analyses have reported that daily consumption of fruit has relevance to a lower incidence of type 2 diabetes [24-28]. It is reported that partial substitution of white rice with certain fruits or dried fruits improved PGRs [16,29,30] and HbA1c levels [31].

In a previous study, on the equi-carbohydrate basis, a 30\% substitution of rice meal with apple preload halved the PGR of a rice meal in an acute test [16]. However, given the scarcity of fruit preload studies, there are more questions to be answered. (1) The simple replacement of rice by apple inevitably led to less protein intake, which would account for the magnitude of PGR and satiety response. What will be the glycemic effect of partially replacing rice meals with fruit preload based on controlled protein intake? (2) Most people are used to enjoying fruit after or between meals without reducing the carbohydrate quantity of the meals, which may result in more calories and a higher glycemic peak [32]. Will the effect of apple preload remain when it is added to a rice meal as an extra carbohydrate load rather than an equi-carbohydrate substitution? (3) Can the hypoglycemic power of fruit preload be generalized to more fruits other than apple and kiwifruit? (4) Compared with high GI starchy foods in daily meals, foods characterized with low energy density and high fiber content are expected for improved satiety [33-35]. If the fruits are given as an extra carbohydrate load, will they elicit greater satiety in line with the energy compensation logic?

In this study, apples, oranges and pears were selected to evaluate the PGR and satiety response of fresh fruits preload to a rice meal with three research hypotheses. (1) Any fruit preload would have some hypoglycemic effect to a rice meal, regardless of the type of the fruit, while the extent of the effect might be different. (2) The fruit preload treatments would curb the glycemic excursion after a rice meal even when the fruit preload was given as an extra carbohydrate load. (3) The satiety response would not be significantly affected by the extra carbohydrate preload.

\section{Materials and Methods}

\subsection{Materials}

Red Fuji apple (Malus pumila Mill.) was produced in Yantai, Shandong Province, China. Hosui pear (Pyrus pyrifolia Nakai.cv.Hosui) was produced in Liaocheng, Shandong Province, China. South Africa's orange (Citrus sinensis (Linn.) Osbeck) was produced in South Africa. White rice (Oryza sativa spp. japonica) was cultivated and milled in Jilin, Jilin Province, China. Hen egg and sesame oil were produced in Beijing, China, bought in the local supermarket.

\subsection{Subjects}

Generally healthy participants aged 18-25 years old college students were recruited through bulletin boards, online advertisements and moments. The subjects were screened according to the following inclusion criteria: (1) free from food allergies and intolerance; (2) with a body mass index (BMI) between 18.5 and $23.9 \mathrm{~kg} / \mathrm{m}^{2}$; (3) weight stable ( $\left.\pm 2 \mathrm{~kg}\right)$ within the last six months; (4) not on diet to gain or to lose weight in the past three months; (5) having three meals regularly; (6) no abnormal blood biochemical test record; (7) no ongoing medical condition or treatment; (8) normal glucose tolerance; (9) a regular menstrual cycle (if women); (10) not pregnant or lactating; (11) no tendency of eating disorders; (12) no diagnosed digestive system diseases, or self-reported frequent gastrointestinal upset; (13) no dependency on caffeine-containing or alcoholic beverages; (14) no dependency on drugs; (15) non-smoker. The self-reported biochemical data were obtained from the physical examination record of the university.

The sample size calculation was done with the PASS 13 Power Analysis and Sample Size software (NCSS, Kaysville, UT, USA). Assuming that the standard deviation (SD) is lower 
than $55.15 \mathrm{mmol} \cdot \mathrm{min} / \mathrm{L}$, a sample size of $n=11$ provided $80 \%$ power to detect a change of $167.8 \mathrm{mmol} \cdot \mathrm{min} / \mathrm{L}$ in iAUC $(p<0.05)$, based on our previous study [16].

Participants interested in the study were screened on the basis of the inclusion criteria and then involved in duplicated oral glucose tolerance tests (OGTT), blood pressure measurement and body composition analysis in the laboratory. Ethics approval was obtained from the China Agricultural University Ethics Committee (ethics number CAUHR2019006) and all eligible individuals provided the informed consent forms. The trial was carried out at the College of Food Science and Nutritional Engineering, China Agricultural University, being in accordance with the Declaration of Helsinki.

\subsection{Study Design}

This study was designed as an acute randomized, crossover trial where participants were randomly assigned to 8 test meals on 8 separate occasions according to the sequence performed by a computer random number generator, with at least one week apart to ensure adequate washout. Subjects were instructed to not consume any fruits or fruit products, and refrain from coffee, tea or alcohol, as well as excessive consumption, intensive exercise and later bedtime on the day prior to each study session. A visit on another day was required if subjects were within 3 days prior to and after the start of menstruation, or did not keep to the above-mentioned requirements.

\subsection{Test Meals}

Eligible subjects underwent 8 test meals consisting of 3 groups: reference, iso-carbohydrate test meals (IC) and hyper-carbohydrate test meals (HC). In the non-preload reference meal, drinking water was given $30 \mathrm{~min}$ before the consumption of white rice containing $50.0 \mathrm{~g}$ available carbohydrates $(\mathrm{AC})(\mathrm{W}+50 \mathrm{R})$. There was a $30 \mathrm{~min}$-interval between the preload food and rice meal in both IC and HC groups. IC were designed to contain $50.0 \mathrm{~g}$ $\mathrm{AC}$ in total, where the fruit or the rice preload contributed $15.0 \mathrm{~g}$ and the rice provided $35.0 \mathrm{~g}$ : (1) rice preload $(\mathrm{R}+35 \mathrm{R})$; (2) orange preload $(\mathrm{O}+35 \mathrm{R})$; (3) apple preload $(\mathrm{A}+35 \mathrm{R})$; (4) pear preload $(\mathrm{P}+35 \mathrm{R})$. HC were given containing a total of $65.0 \mathrm{~g} \mathrm{AC}$ where the fruit preload contributed $15.0 \mathrm{~g}$ and the rice provided $50.0 \mathrm{~g}$ : (1) orange preload $(\mathrm{O}+50 \mathrm{R})$; (2) apple preload $(\mathrm{A}+50 \mathrm{R})$; (3) pear preload $(\mathrm{P}+50 \mathrm{R})$. The composition and nutrient content of the test meals are shown in Table 1.

Table 1. Composition and nutrient content of test meals (per serving) ${ }^{1}$.

\begin{tabular}{|c|c|c|c|c|c|c|c|c|c|c|}
\hline Sample & $\begin{array}{l}\text { Polished } \\
\text { Rice } \\
\text { (g) }\end{array}$ & $\begin{array}{c}\text { Fruit } \\
\text { (g) }\end{array}$ & $\begin{array}{c}\text { Egg } \\
\text { White }^{2} \\
\text { (g) }\end{array}$ & $\begin{array}{c}\text { Sesame } \\
\text { Oil }^{3} \\
\text { (g) }\end{array}$ & $\begin{array}{c}\mathrm{AC}^{4} \\
(\mathrm{~g})\end{array}$ & $\begin{array}{l}\text { Protein } \\
\text { (g) }\end{array}$ & $\begin{array}{l}\text { Fat } \\
\text { (g) }\end{array}$ & $\begin{array}{c}\text { Dietary } \\
\text { Fiber (g) }\end{array}$ & $\begin{array}{c}\text { Meal } \\
\text { Size } \\
(\mathrm{g})\end{array}$ & $\begin{array}{c}\text { Energy } \\
\text { (kcal) }\end{array}$ \\
\hline$W+50 R$ & 143.1 & - & - & - & 50.0 & 7.0 & 0.6 & 1.00 & 383.5 & 845.6 \\
\hline$R+35 R$ & 143.1 & - & 2.7 & 2.5 & 50.0 & 9.7 & 2.1 & 1.00 & 336.3 & 961.5 \\
\hline $\mathrm{O}+35 \mathrm{R}$ & 93.3 & 191.6 & - & - & 50.0 & 9.7 & 2.1 & 32.46 & 336.3 & 981.8 \\
\hline$A+35 R$ & 93.3 & 134.8 & 3.5 & 0.5 & 50.0 & 9.7 & 2.1 & 12.48 & 336.3 & 931.2 \\
\hline$P+35 R$ & 93.3 & 240.4 & 2.6 & - & 50.0 & 9.7 & 2.1 & 20.88 & 336.3 & 1147.1 \\
\hline $\mathrm{O}+50 \mathrm{R}$ & 143.1 & 191.6 & - & - & 65.0 & 11.8 & 2.3 & 32.46 & 383.5 & 1232.6 \\
\hline$A+50 R$ & 143.1 & 134.8 & - & - & 65.0 & 8.3 & 1.7 & 12.48 & 383.5 & 1121.9 \\
\hline$P+50 R$ & 143.1 & 240.4 & - & - & 65.0 & 9.2 & 2.3 & 20.88 & 383.5 & 1352.8 \\
\hline
\end{tabular}

${ }^{1}$ Nutrient content data were acquired through manufacturers and determination experiments. ${ }^{2}$ Egg white was used to balance the protein contents in the IC group. ${ }^{3}$ Sesame oil was used to adjust the fat contents in the IC group. ${ }^{4} \mathrm{AC}$, available carbohydrate. ${ }^{5}$ The water for weight balance was included. $\mathrm{R}$, rice; $\mathrm{O}$, oranges; $\mathrm{A}$, apples; $\mathrm{P}$, pears; $\mathrm{W}$, water.

The sugar fractions of the three fruits are shown in Figure 1. The pear and apple had a higher proportion of fructose than the orange did. In a $15.0 \mathrm{~g}$ AC portion of preload fruits, the contents of fructose, sucrose and glucose were 4.7, 5.4 and $4.9 \mathrm{~g}$ for orange, 8.7, 1.7 and $4.6 \mathrm{~g}$ for apple, and 8.6, 0.9 and $5.5 \mathrm{~g}$ for pear, respectively. 

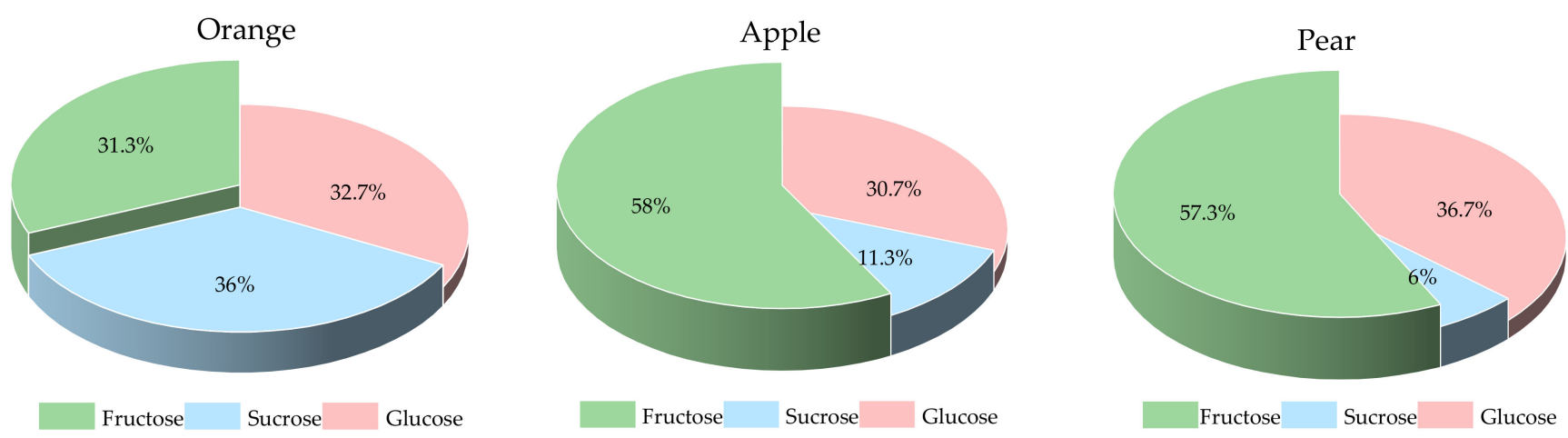

Figure 1. The sugar fractions of the three fruits.

\subsection{PGR Assessment}

On each test day, the subjects came to the laboratory at 8:15 a.m. after a $12 \mathrm{~h}$ overnight fast and had two fasting plasma glucose samples at $-10 \mathrm{~min}$ and $0 \mathrm{~min}$ after a short rest. Then the preload food or water was provided to the subjects at $0 \mathrm{~min}$ and the food was ingested within $5 \mathrm{~min}$. The white rice was served $30 \mathrm{~min}$ after the start of the preload and was ingested within $10 \mathrm{~min}$. Then $200 \mathrm{~mL}$ of water at room temperature was supplied at $120 \mathrm{~min}$ and was consumed before the end of the test. An additional 8 blood samples at 15, $30,45,60,90,120,150$ and 180 min were obtained by finger-prick, measured by glucometer (LifeScan Inc., Milpitas, CA, USA) using the glucose oxidase method, with the first drop of blood discarded.

\subsection{Satiety Assessment}

The subjective satiety during each test session was assessed by visual analog scale (VAS) [36], which is a 100-mm rating scale with the statement "extremely hungry" on one end and "extremely full" on the other end. The subjects ranked their level of satiety at $0,15,30,45,60,90,120,150,180 \mathrm{~min}$, also at the end time of preload food and rice meal consumption.

\subsection{Primary Outcome and Statistical Analysis}

The fasting glucose for each subject was taken as the mean value of the glucose concentrations at $-10 \mathrm{~min}$ and $0 \mathrm{~min}$. The glycemic data analysis was based on the glucose change value relative to the fasting glucose. The incremental areas under the curve (iAUC) of PGR were calculated using the trapezoidal rule, ignoring the area beneath the fasting glucose level. The incremental peak glucose concentrations (IPG) and the maximum amplitudes of glucose excursion in $180 \mathrm{~min}\left(\mathrm{MAGE}_{0-180}\right)$ were defined. In order to adjust the amount of available carbohydrates of the test meals, the area of PGR contributed by per gram of available carbohydrate (AAC) was defined to predict the change of glycemic parameters, where $\mathrm{AAC}=\mathrm{iAUC} \mathrm{A}_{0-180}(\mathrm{mmol} \cdot \mathrm{min} / \mathrm{L}) /$ the available carbohydrates of test meals (g).

The satiety data analysis was based on the VAS change value relative to the baseline. The incremental areas under the curve (iAUC) of postprandial satiety responses and the incremental peak of satiety (IPS) were calculated. In order to adjust the energy intake of the test meals, the peak satiety density (PSD) was defined to predict the change of satiety, where PSD = IPS (mm)/the energy of test meal (MJ).

The statistical analysis was performed by an investigator blinded to the study group, using the SPSS version 21.0 (SPSS Inc. Chicago, IL, USA). Two-factor repeated-measures ANOVA assessed the effects of treatment $x$ time on PGR and satiety. One-way analysis of variance ANOVA and Duncan's multiple range test were performed to compare the effects of test meals on the above-mentioned characteristic values of PGR and satiety response. 
The variables are presented as the mean \pm standard deviation (SD) or the mean value with standard error (SE), with $p<0.05$ considered statistically significant.

\section{Results}

\subsection{Subject Characteristics}

A total of 19 participants were enrolled, where 14 subjects met the OGTT criteria with no one dropped out throughout the test period (Figure 2). All of them were female university students aged $22.0 \pm 1.3$ (mean $\pm \mathrm{SD}$ ) years, with a mean (SD) BMI of 19.2 (1.2) $\mathrm{kg} / \mathrm{m}^{2}$. All data of 14 subjects were included in the analysis.

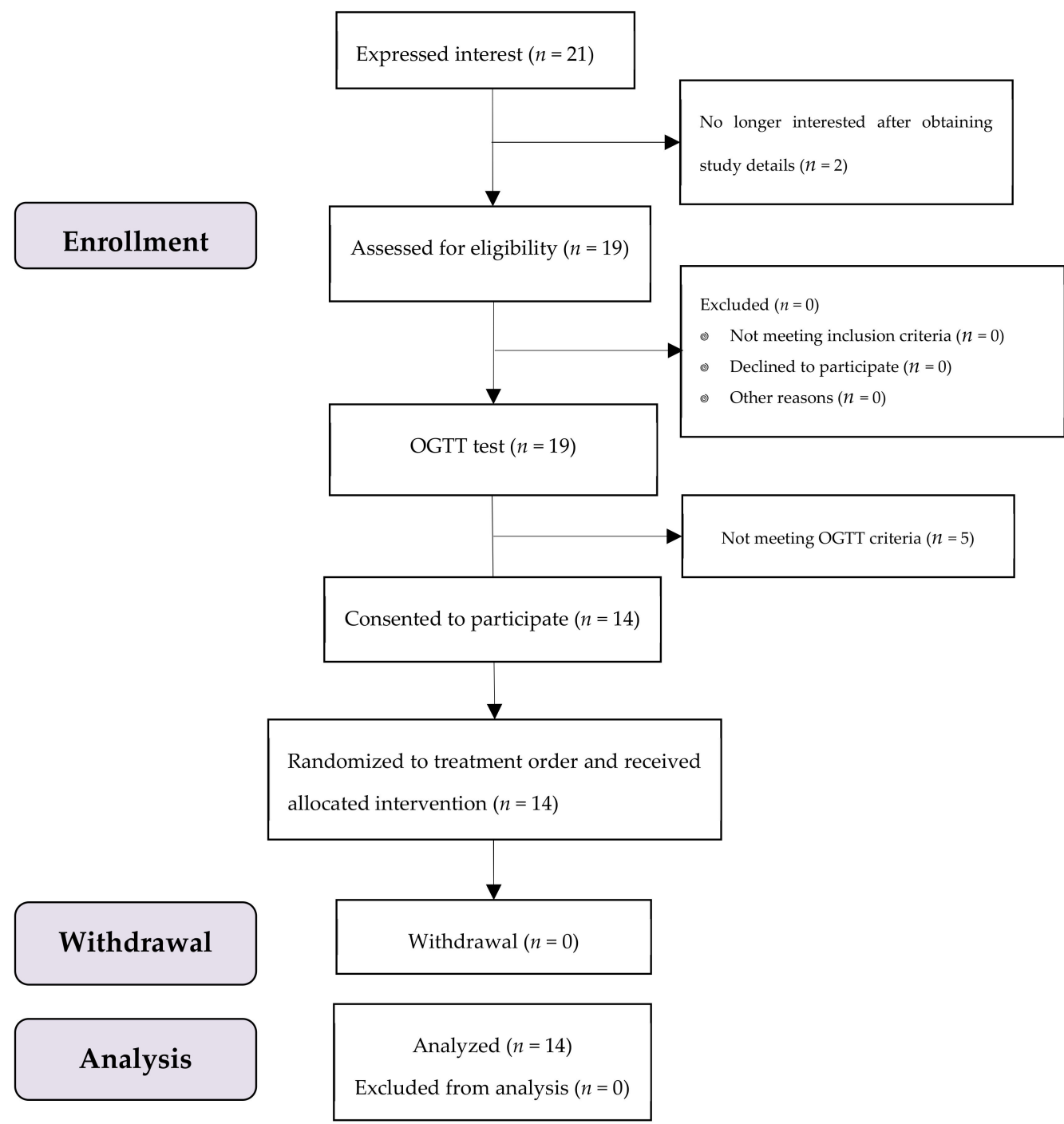

Figure 2. The study subjects flow diagram.

\section{2. $P G R$}

There was no significant difference in baseline (i.e., $0 \mathrm{~min}$ ) blood glucose between all the test meals. The PGRs for all test meals are shown in Figure 3. The PGR pattern of preload meals was characterized by double small peaks instead of one sharp peak in the case of the $\mathrm{W}+50 \mathrm{R}$. One of the peaks appeared immediately following the preload, while another peak showed up long after the rice meal. Though the preloads led to higher glucose levels at 15 and $30 \mathrm{~min}$, all of them dramatically reduced the postprandial glucose at 60 and $90 \mathrm{~min}(p<0.001)$ in both IC and HC groups, and at $150 \mathrm{~min}$ in the IC group $(p<0.01)$. In the IC group (Figure $3 \mathrm{a})$, the $\mathrm{R}+35 \mathrm{R}$ and $\mathrm{A}+35 \mathrm{R}$ cut down the blood glucose level at 120 min compared with $\mathrm{W}+50 \mathrm{R}(p<0.05)$. The $\mathrm{P}+35 \mathrm{R}$ and $\mathrm{A}+35 \mathrm{R}$ 
further lowered the glucose level at 90 min compared with $\mathrm{R}+35 \mathrm{R}(p<0.05)$. In the HC group (Figure $3 \mathrm{~b}$ ), the $\mathrm{O}+50 \mathrm{R}$ also cut down the glucose level at 120 min compared with $\mathrm{W}+50 \mathrm{R}(p<0.05)$. Among the preload meals, the orange preload showed the highest incremental values at 15 and $30 \mathrm{~min}$ in both IC and HC groups.

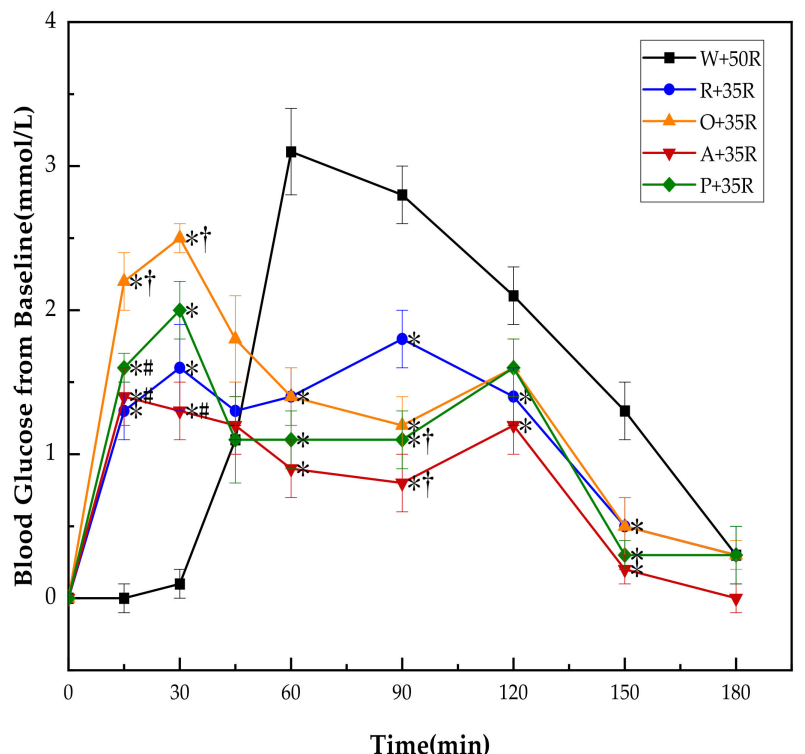

(a)

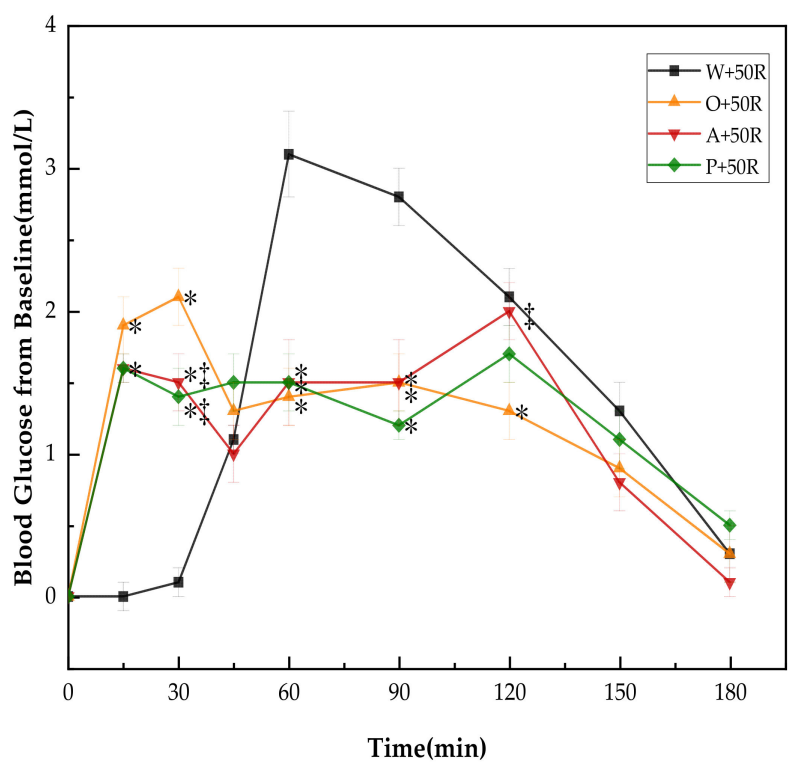

(b)

Figure 3. (a) PGRs for reference and IC test meals; (b) PGRs for reference and HC test meals. G, glucose; $\mathrm{R}$, rice; $\mathrm{O}$, oranges; A, apples; P, pears; W, water. Data are presented as the mean values with their standard errors, $n=14$. ${ }^{*}$ Test meals different from $W+50 R,{ }^{\dagger}$ Test meals different from $R+35 R$, ${ }^{\#}$ Test meals different from $O+35 R, \ddagger$ Test meals different from $O+50 R$ $(p<0.05)$.

\subsection{PGR Characteristics}

As shown in Table 2, $\mathrm{A}+35 \mathrm{R}$ showed the lowest $\mathrm{iAUC}_{0-60}$ among all preload test meals. All the preload test meals elicited smaller iAUC $60-120$ than $\mathrm{W}+50 \mathrm{R}$ did $(p<0.001)$, but only the $\mathrm{A}+35 \mathrm{R}$ had a significant lower iAUC $\mathrm{C}_{60-120}$ than $\mathrm{R}+35 \mathrm{R}(p<0.01)$. The preload meals decreased the iAUC ${ }_{120-180}$ significantly compared with $\mathrm{W}+50 \mathrm{R}(p<0.05)$ in the IC group, but not in the HC group. In terms of iAUC $\mathrm{C}_{0-180}, \mathrm{~A}+35 \mathrm{R}$ was the lowest and achieved a $45.7 \%$ and $29.1 \%$ decrease compared with $\mathrm{W}+50 \mathrm{R}(p<0.001)$ and $\mathrm{R}+35 \mathrm{R}$ $(p=0.055)$, respectively.

Table 2. PGR characteristics of test meals in $180 \mathrm{~min}(n=14)$.

\begin{tabular}{|c|c|c|c|c|c|c|c|c|c|c|}
\hline \multirow{2}{*}{ Sample } & \multicolumn{2}{|c|}{ iAUC $_{0-60}$} & \multicolumn{2}{|c|}{ iAUC $_{60-120}$} & \multicolumn{2}{|c|}{ iAUC $_{120-180}$} & \multicolumn{2}{|c|}{ iAUC $_{0-180}$} & \multicolumn{2}{|c|}{ AAC } \\
\hline & Mean & SE & Mean & SE & Mean & SE & Mean & SE & Mean & SE \\
\hline$W+50 R$ & $44.8^{\mathrm{a}}$ & 4.9 & $159.8^{\mathrm{a}}$ & 7.3 & $75.3^{a}$ & 9.0 & $279.8^{a}$ & 8.9 & $5.6^{\mathrm{a}}$ & 0.2 \\
\hline$R+35 R$ & $73.6 b^{c}$ & 9.3 & $96.0^{b}$ & 10.0 & $44.6^{\mathrm{bc}}$ & 8.9 & $214.2^{a b c}$ & 23.5 & $4.3^{b}$ & 0.5 \\
\hline$O+35 R$ & $106.9^{d}$ & 8.0 & $81.3^{b c}$ & 9.8 & $45.3^{b c}$ & 7.4 & $233.5^{a b}$ & 22.2 & $4.7^{\mathrm{ab}}$ & 0.4 \\
\hline$A+35 R$ & $65.0^{\mathrm{ab}}$ & 6.2 & $57.1^{\mathrm{c}}$ & 8.6 & $29.7^{c}$ & 5.5 & $151.8^{c}$ & 16.3 & $3.0^{\mathrm{c}}$ & 0.3 \\
\hline$P+35 R$ & $79.6^{\text {bc }}$ & 7.7 & $73.1^{b c}$ & 11.3 & $41.9^{b c}$ & 7.0 & $194.5^{b c}$ & 22.6 & $3.9^{b c}$ & 0.5 \\
\hline $\mathrm{O}+50 \mathrm{R}$ & $90.4^{\mathrm{cd}}$ & 9.1 & $86.0^{b c}$ & 9.0 & $51.6^{\mathrm{abc}}$ & 7.6 & $228.0^{a b}$ & 23.3 & $3.5^{b c}$ & 0.4 \\
\hline$A+50 R$ & $72.3^{b c}$ & 8.5 & $97.3^{b}$ & 11.8 & $57.0^{\mathrm{ab}}$ & 8.3 & $226.5^{\mathrm{ab}}$ & 24.8 & $3.5 \mathrm{bc}$ & 0.4 \\
\hline$P+50 R$ & $78.2^{b c}$ & 6.4 & $84.2^{b c}$ & 8.2 & $66.2^{a b}$ & 9.0 & $228.6^{a b}$ & 20.5 & $3.5^{b c}$ & 0.3 \\
\hline
\end{tabular}

$\mathrm{G}$, glucose; $\mathrm{R}$, rice; $\mathrm{O}$, oranges; $\mathrm{A}$, apples; $\mathrm{P}$, pears; $\mathrm{W}$, water. ${ }^{\mathrm{a}, \mathrm{b}, \mathrm{c}, \mathrm{d}}$ Different superscript letters denote that mean values within a column are significantly different $(p<0.05)$.

Compared with the $\mathrm{W}+50 \mathrm{R}$, all the preload meals except for $\mathrm{O}+35 \mathrm{R}$ achieved a significant decrease in AAC $(p<0.05)$, which represents the area contributed by per gram 
of available carbohydrate. The AAC of A + 35R was the smallest and achieved a $46.4 \%$ and $30.2 \%$ decrease compared with that of the $W+50 R(p<0.001)$ and $R+35 R(p<0.05)$, respectively.

The IPG and MAGE ${ }_{0-180}$ for all test foods are shown in Figure 4. The IPG and the MAGE $_{0-180}$ of the preload test meals were significantly lower than that of the $\mathrm{W}+50 \mathrm{R}$ $(p<0.001)$. Compared with the $\mathrm{W}+50 \mathrm{R}$, the $\mathrm{A}+35 \mathrm{R}$ had a $51.3 \%$ and $46.1 \%$ reduction in the IPG and MAGE $0-180$, respectively. The $\mathrm{A}+35 \mathrm{R}$ also attained a significant decrease $(p<0.01)$ compared with $\mathrm{O}+35 \mathrm{R}$ in terms of both the IPG and the MAGE ${ }_{0-180}$.

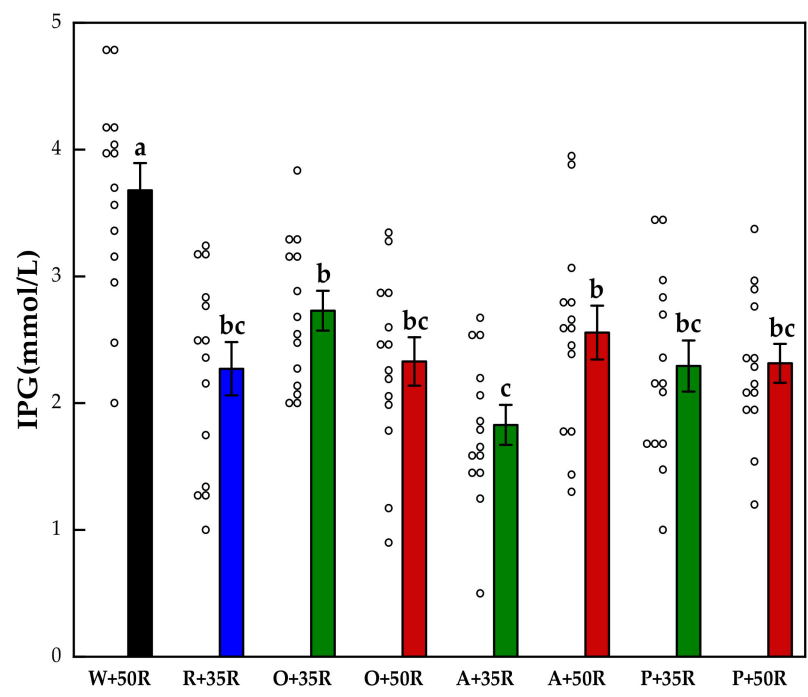

(a)

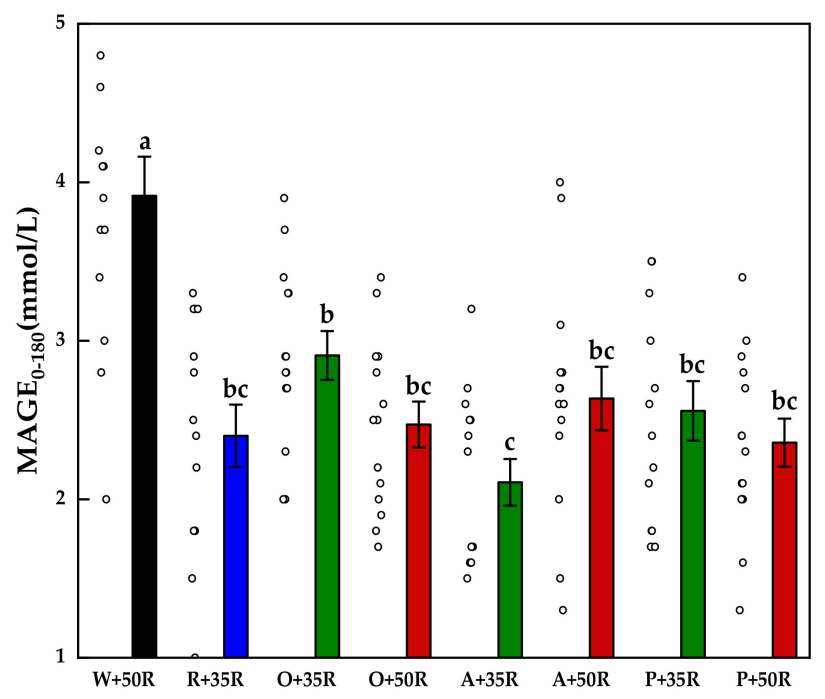

(b)

Figure 4. (a) IPG, (b) MAGE 180 for test meals. The hollow circles indicate the data of each subject, the columns indicate the mean value, the error bar indicates the SE value. Significant differences $(p<0.05)$ are represented by different letters.

\subsection{Subjective Satiety}

As shown in Figure 5, the A + 35R, P + 35R, O + 50R and P + 50R showed significantly higher incremental satiety values than $\mathrm{W}+50 \mathrm{R}$ only at $30 \mathrm{~min}$. There were no differences at any other time point between $\mathrm{W}+50 \mathrm{R}$ and the test meals of the HC group.

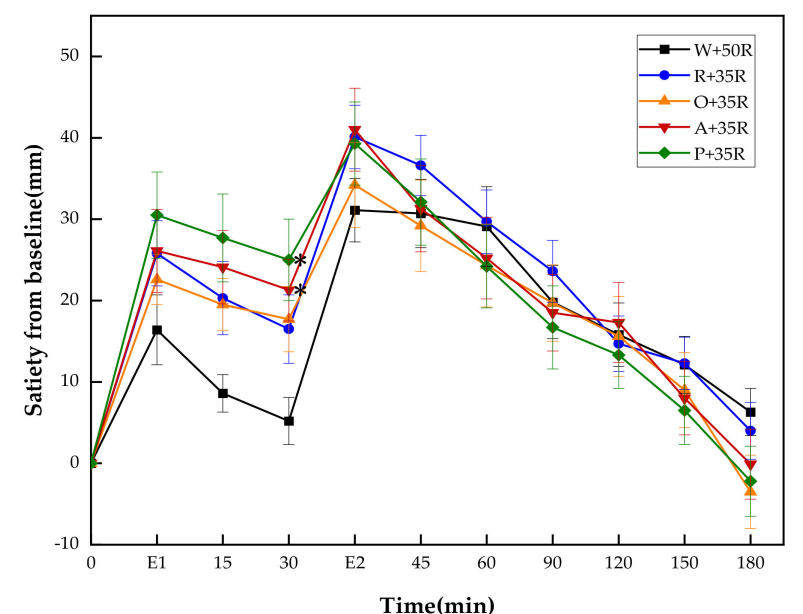

(a)

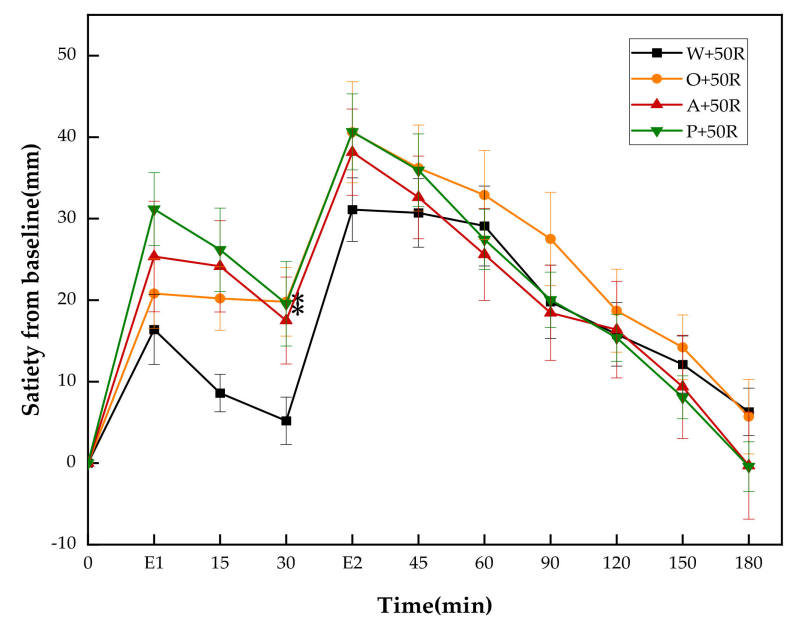

(b)

Figure 5. (a) Satiety responses for reference and IC test meals; (b) satiety responses for reference and HC test meals. E1, the end point of preload consumption; E2, the end point of rice consumption. $G$, glucose; $\mathrm{R}$, rice; $\mathrm{O}$, oranges; $\mathrm{A}$, apples; $\mathrm{P}$, pears; $\mathrm{W}$, water. Data are given as mean $\pm \mathrm{SE}, n=14$. $^{*}$ Test meals different from $\mathrm{W}+50 \mathrm{R}$. 
There were no significant differences between all test meals in any of the satiety characteristics except for PSD. The $\mathrm{P}+50 \mathrm{R}$ showed a significant reduction of PSD compared with $\mathrm{W}+50 \mathrm{R}$ and $\mathrm{A}+35 \mathrm{R}(p<0.05)$.

\section{Discussion}

In the present study, the apple and pear were chosen because both of them are among low GI temperate fruits associated with reduced risk of diabetes [32]. Apples are especially well-known for being a rich source of flavonoids, phenolic acids, anthocyanidins and pectin [37], which might add points to glycemic homeostasis in the long run [38,39]. Orange is a number of citrus fruits, which are rich sources of vitamin C, carotenoids and phytochemicals contributing to the prevention of diabetes and diabetic complications [40,41]. The tropical fruits such as durian, mango and banana were not included in the trial as the intake of tropical fruits was reported to be positively associated with the risk of diabetes in the Asian population [32].

In this study, all the preload test meals led to a sharp decrease in PGR, regardless of the preload manner, i.e., IC or HC. Even when loaded with additional $15 \mathrm{~g} \mathrm{AC}$, all fruit preloads significantly resulted in lower IPG and $\mathrm{MAGE}_{0-180}$ than the $\mathrm{W}+50 \mathrm{R}$ control meal did, suggesting that fruits ingested $30 \mathrm{~min}$ prior to a high carbohydrate meal could be explored as a simple and practical hypoglycemic strategy.

It is important to verify the effect of the extra fruit preload because most people would not balance their carbohydrate intake of a meal after enjoying pre-meal fruits. The iAUC $_{0-180} \mathrm{~s}$ of $\mathrm{HC}$ test meals (containing $65 \mathrm{~g} \mathrm{AC}$ ) were not significantly lower than that of the control group ( $\mathrm{W}+50 \mathrm{R}$, containing $50 \mathrm{~g} \mathrm{AC}$ ), but the area of PGR contributed by per gram of AC (AAC) of the preload meals achieved a significant reduction. Nevertheless, the hypoglycemic effects varied in degree despite the same carbohydrate, protein and fat contents in the IC test meals.

The IC tests reproduced the result in the previous study [16] that the apple preload halved the iAUC ${ }_{0-180}$, IPG and MAGE ${ }_{0-180}$. However, when preloading orange, the corresponding reduction was merely $16.5 \%, 27.0 \%$ and $25.6 \%$ respectively, compared with that of the $\mathrm{W}+50 \mathrm{R}$ control. The result of the pear preload was in between that of the apple and orange.

The disparity of PGR of fruits preload in the IC group may be partly attributed to the fructose content. Although a large amount of fructose was implicated for playing a role in the development of diabetes [42], several meta-analyses indicated that energymatched substitution of fructose (especially from fruit) for refined starches could improve $\mathrm{HbA1c}$ without any negative metabolic effects [43-45]. Previous literature suggested the 'catalytic' fructose doses ( $\leq 36 \mathrm{~g} / \mathrm{d})$ might be beneficial [46], and a range of 7-10 $\mathrm{g}$ fructose was reported to be able to promote glucose metabolism and improve PGR in some studies $[14,47-49]$. The fructose content of orange accounts for only $31 \%$ of its soluble sugar, while the apple and pear account for more than $55 \%$. The fructose provided by the apple and pear preload was $8.7 \mathrm{~g}$ and $8.6 \mathrm{~g}$, respectively, while the orange was only $4.5 \mathrm{~g}$, falling out of the reported effective range of 7-10 g.

Growing evidence indicates that dietary fruit consumption is conducive to the prevention of type 2 diabetes [26-28,50]. However, the key component and biological mechanism responsible for the beneficial effects of fruits on PGR is yet to be elucidated. A study claimed that the sugar component extracted from kiwifruit failed to reduce the PGR of a co-ingested high GI meal as the kiwifruit did [51]. However, when given as a preload, the apple sugar solution was $39 \%$ as effective as an apple in terms of lowering the glycemic iAUC of rice meals [16].

It is possible that several factors contributed to the striking hypoglycemic effect of fruit preloads: (1) the preload effect, which could also be elicited by sugar or starch; (2) the action of an appropriate amount of fructose, which improved the hepatic glycogen metabolism [52,53]; (3) the effect of the phytochemicals in the fruits, which might retard 
the process of digestion and improve the insulin sensitivity [54,55]; (4) the fiber and texture of the fruits, which might delay the gastric emptying [56].

A number of sugar-containing preloads, including fructose [14], glucose [15], a mixture of fructose and glucose [16], fruits [16,29], dried apple [57], and vegetable drinks [58,59], were reported to be able to alleviate postprandial glycemic excursion to some degree. In the present study, rice preload of $15 \mathrm{~g} A C(\mathrm{R}+35 \mathrm{R})$ also achieved a considerable drop of the IPG and MAGE 180 compared with the $\mathrm{W}+50 \mathrm{R}$ control meal. This result confirmed the preload effect of starchy food reported in previous studies $[29,60]$.

It is interesting that, after the preload meals, the PGR curves manifested a smalldouble-peak curve instead of the one-sharp-peak curve in $\mathrm{W}+50 \mathrm{R}$ control. This unique pattern is in line with the result of our previous study [16] and an earlier report [15]. The second peak would appear at 30-45 min after the ingestion of the high GI meals in glucose [15], starch preload [60] and vegetable drinks [58,59], but in the present study, the second peaks were delayed to $60-90 \mathrm{~min}$.

A few preload studies investigated the insulin and incretin pattern of carbohydrate preloads. After $20 \mathrm{~g}$ glucose preload, the insulin level did elevate right after the ingestion but the postprandial peak value had no significant difference with that of the control meal [15]. The rice porridge and the kiwifruit preload meal elicited no significant increase in terms of the iAUCs of postprandial insulin, glucagon and ghrelin, compared to the control [29]. Hence, though there were no metabolic markers other than blood glucose in the present study, it is not reasonable to attribute the carbohydrate preload effect on glucose metabolism to a substantial increase of insulin. A possible explanation of the preload action, such as the "early onset of insulin" or the "improved insulin sensitivity" hypotheses, need to be tested in a future study.

The pre-meal apple treatment highlighted a combined action of the fructose, the phytochemicals, and the texture factors, in addition to the preload effect. Compared with the $R+35 R$, the $i_{A U C}{ }_{60-120}$ and AAC of $A+35 R$ decreased significantly. The IPG and MAGE $_{0-180}$ of $A+35 R$ were the lowest, $21.7 \%$ and $12.5 \%$ lower than that of $R+35 R$. In addition, the $i A U C_{0-180}$ of $A+35 R$ was $29.1 \%$ lower than that of $R+35 R$. It is noticed that the apple had higher fructose content than orange and was chewier than pear. A previous study reported that chewy texture and slower eating rate may increase the release of GLP-1 and peptide YY (PYY), which play a role in enhancing the insulin action [61,62].

With respect to the timing of fruit intake on the satiety of a meal, the results were inconsistent in limited studies. A previous study reported that consuming fruit before a meal reduced the subsequent energy intake by $166 \mathrm{kcal}$ [63], while another study found that co-ingestion of apple and rice elicited a greater satiety response compared to the corresponding preload meal [16]. The present study found that the $\mathrm{iAUC}_{0-180}$ of all other test meals, either the HC or IC groups, had no significant difference with that of the $\mathrm{W}+50 \mathrm{R}$. There was no significant difference in the satiety measured by VAS between the HC (65 g $\mathrm{AC}$ ) and the $\mathrm{W}+50 \mathrm{R}$ control (50 $\mathrm{g} \mathrm{AC})$, suggesting an inadequate energy compensation in the case of extra sugar preload. It is noticed that the PSD of A + 35R was significantly higher than that of the P + 50R, in spite of the smaller bulk volume (134.8 g vs. $240.4 \mathrm{~g}$ ), less rice and the similar fructose contents. The chewy texture and high pectin content in apples might play a role in its higher satiety response compared with pear. Given that daily fruit intake is beneficial to the prevention of chronic disease and some cancers [21], taking fruit as a preload of carbohydrate-dense meals is only a matter of timing instead of a risk of increasing energy intake.

To the best of our knowledge, this is the first study to investigate the effect of different types of fresh fruit preload on postprandial glycemia and satiety based on IC and HC (50 g and $65 \mathrm{~g} \mathrm{AC}$ ) modes. In this study, the macronutrient contents in iso-carbohydrate test meals and the meal size were carefully controlled to minimize possible confounding factors. However, this study is an acute test in healthy subjects. The effect of fruit preload in the prediabetic and the diabetic is still to be explored in a long-term intervention study. The exact mechanism of the hypoglycemic effect of carbohydrate preload needs to be elucidated 
by investigating the pattern of insulin and other gut hormones, the rate of gastric emptying and digestion, as well as the regulation of metabolic pathways.

\section{Conclusions}

In conclusion, the present study demonstrated that fruit preloads containing $15 \mathrm{~g}$ AC, either in iso-carbohydrate or hyper-carbohydrate manner, dramatically improved the PGR and reduced the glycemic excursion. Compared with the orange and pear, the apple preload performed the best in curbing the IPG and the MAGE ${ }_{0-180}$. The result of the study encourages further exploration of the hypoglycemic effect of fruit preload for people in need of PGR management.

Author Contributions: Conceptualization, Z.F.; methodology, Z.F., X.L., J.L. and R.Z.; formal analysis, X.L.; investigation, X.L., J.L., A.L., W.Z. and Y.W.; writing-original draft preparation, X.L.; writingreview and editing, Z.F. All authors have read and agreed to the published version of the manuscript.

Funding: This research was funded by the Nutrition Development Fund of China Agricultural University, 201801.

Institutional Review Board Statement: The study was conducted according to the guidelines of the Declaration of Helsinki, and approved by the Ethics Committee of China Agricultural University (CAUHR-2019006).

Informed Consent Statement: Informed consent was obtained from all subjects involved in the study. Written informed consent has been obtained from the subjects to publish this paper.

Data Availability Statement: The data presented in this study are available on request from the corresponding author.

Acknowledgments: We sincerely thank all the volunteers who participated in the blood glucose tests for their time and corporation.

Conflicts of Interest: The authors declare no conflict of interest.

\section{References}

1. Lin, M.-H.A.; Wu, M.-C.; Lu, S.; Lin, J. Glycemic index, glycemic load and insulinemic index of Chinese starchy foods. World J. Gastroenterol. 2010, 16, 4973-4979. [CrossRef]

2. Yang, C.-H.; Chang, C.-W.; Lin, J. White Rice Glycemic Index Measured in Venous and Capillary Blood Samples. Food Sci. Technol. Res. 2017, 23, 297-304. [CrossRef]

3. Boers, H.M.; Hoorn, J.S.T.; Mela, D.J. A systematic review of the influence of rice characteristics and processing methods on postprandial glycaemic and insulinaemic responses. Br. J. Nutr. 2015, 114, 1035-1045. [CrossRef]

4. Robert, S.D.; Ismail, A.A.-S.; Rosli, W.I.W. Reduction of postprandial blood glucose in healthy subjects by buns and flatbreads incorporated with fenugreek seed powder. Eur. J. Nutr. 2016, 55, 2275-2280. [CrossRef] [PubMed]

5. Hu, E.A.; Pan, A.; Malik, V.; Sun, Q. White rice consumption and risk of type 2 diabetes: Meta-analysis and systematic review. Br. Med. J. 2012, 344, e1454. [CrossRef] [PubMed]

6. Ren, G.; Qi, J.; Zou, Y. Association between intake of white rice and incident type 2 diabetes-An updated meta-analysis. Diabetes Res. Clin. Pract. 2021, 172, 108651. [CrossRef] [PubMed]

7. Gentilcore, D.; Chaikomin, R.; Jones, K.; Russo, A.; Feinle-Bisset, C.; Wishart, J.M.; Rayner, C.K.; Horowitz, M. Effects of Fat on Gastric Emptying of and the Glycemic, Insulin, and Incretin Responses to a Carbohydrate Meal in Type 2 Diabetes. J. Clin. Endocrinol. Metab. 2006, 91, 2062-2067. [CrossRef] [PubMed]

8. Ma, J.; Stevens, J.E.; Cukier, K.; Maddox, A.F.; Wishart, J.M.; Jones, K.; Clifton, P.; Horowitz, M.; Rayner, C.K. Effects of a Protein Preload on Gastric Emptying, Glycemia, and Gut Hormones After a Carbohydrate Meal in Diet-Controlled Type 2 Diabetes. Diabetes Care 2009, 32, 1600-1602. [CrossRef]

9. Tricò, D.; Baldi, S.; Tulipani, A.; Frascerra, S.; Macedo, M.P.; Mari, A.; Ferrannini, E.; Natali, A. Mechanisms through which a small protein and lipid preload improves glucose tolerance. Diabetologia 2015, 58, 2503-2512. [CrossRef]

10. Li, C.-J.; Norstedt, G.; Hu, Z.-G.; Yu, P.; Li, D.-Q.; Li, J.; Yu, Q.; Sederholm, M.; Yu, D.-M. Effects of a Macro-Nutrient Preload on Type 2 Diabetic Patients. Front. Endocrinol. 2015, 6, 139. [CrossRef]

11. Watson, L.E.; Phillips, L.K.; Wu, T.; Bound, M.J.; Checklin, H.L.; Grivell, J.; Jones, K.L.; Clifton, P.M.; Horowitz, M.; Rayner, C.K. A whey/guar "preload" improves postprandial glycaemia and glycated haemoglobin levels in type 2 diabetes: A 12-week, single-blind, randomized, placebo-controlled trial. Diabetes Obes. Metab. 2019, 21, 930-938. [CrossRef] 
12. Jakubowicz, D.; Froy, O.; Ahren, B.; Boaz, M.; Landau, Z.; Bar-Dayan, Y.; Ganz, T.; Barnea, M.; Wainstein, J. Incretin, insu-linotropic and glucose-lowering effects of whey protein pre-load in type 2 diabetes: A randomised clinical trial. Diabetologia 2014, 57, 1807-1811. [CrossRef] [PubMed]

13. Ma, J.; Jesudason, D.R.; Stevens, J.E.; Keogh, J.; Jones, K.; Clifton, P.M.; Horowitz, M.; Rayner, C.K. Sustained effects of a protein 'preload' on glycaemia and gastric emptying over 4 weeks in patients with type 2 diabetes: A randomized clinical trial. Diabetes Res. Clin. Pract. 2015, 108, e31-e34. [CrossRef] [PubMed]

14. Heacock, P.M.; Hertzler, S.R.; Wolf, B.W. Fructose Prefeeding Reduces the Glycemic Response to a High-Glycemic Index, Starchy Food in Humans. J. Nutr. 2002, 132, 2601-2604. [CrossRef]

15. Akhavan, T.; Luhovyy, B.L.; Panahi, S.; Kubant, R.; Brown, P.H.; Anderson, G.H. Mechanism of action of pre-meal con-sumption of whey protein on glycemic control in young adults. J. Nutr. Biochem. 2014, 25, 36-43. [CrossRef] [PubMed]

16. Lu, J.; Zhao, W.; Wang, L.; Fan, Z.; Zhu, R.; Wu, Y.; Zhou, Y. Apple Preload Halved the Postprandial Glycaemic Response of Rice Meal in Healthy Subjects. Nutrients 2019, 11, 2912. [CrossRef] [PubMed]

17. World Health Organization. Sugar Intake for Adults and Children; WHO: Geneva, Switzerland, 2015; p. 49.

18. Lustig, R.H.; Schmidt, L.A.; Brindis, C.D. The toxic truth about sugar. Nature 2012, 482, 27-29. [CrossRef] [PubMed]

19. Hannou, S.; Haslam, D.; McKeown, N.M.; Herman, M.A. Fructose metabolism and metabolic disease. J. Clin. Investig. 2018, 128, 545-555. [CrossRef]

20. Carvalho, C.T.; de Souza, M.Z.; Arbex, N.; Sá, D.; de Sá, D.A.; de Sá, L.B.; Arbex, A.K. The Role of Fructose in Public Health and Obesity. Health 2018, 10, 434-441. [CrossRef]

21. Angelino, D.; Godos, J.; Ghelfi, F.; Tieri, M.; Titta, L.; Lafranconi, A.; Marventano, S.; Alonzo, E.; Gambera, A.; Sciacca, S.; et al. Fruit and vegetable consumption and health outcomes: An umbrella review of observational studies. Int. J. Food Sci. Nutr. 2019, 70, 652-667. [CrossRef]

22. Aune, D.; Giovannucci, E.; Boffetta, P.; Fadnes, L.T.; Keum, N.; Norat, T.; Greenwood, D.C.; Riboli, E.; Vatten, L.J.; Tonstad, S. Fruit and vegetable intake and the risk of cardiovascular disease, total cancer and all-cause mortality-a systematic review and dose-response meta-analysis of prospective studies. Int. J. Epidemiol. 2017, 46, 1029-1056. [CrossRef] [PubMed]

23. Lapuente, M.; Estruch, R.; Shahbaz, M.; Casas, R. Relation of Fruits and Vegetables with Major Cardiometabolic Risk Factors, Markers of Oxidation, and Inflammation. Nutrients 2019, 11, 2381. [CrossRef] [PubMed]

24. Du, H.; Li, L.; Bennett, D.; Guo, Y.; Turnbull, I.; Yang, L.; Bragg, F.; Bian, Z.; Chen, Y.; Chen, J.; et al. Fresh fruit consumption in relation to incident diabetes and diabetic vascular complications: A 7-y prospective study of 0.5 million Chinese adults. PLoS Med. 2017, 14, e1002279. [CrossRef] [PubMed]

25. Muraki, I.; Imamura, F.; E Manson, J.; Hu, F.B.; Willett, W.C.; van Dam, R.; Sun, Q. Fruit consumption and risk of type 2 diabetes: Results from three prospective longitudinal cohort studies. Br. Med. J. 2013, 347, f5001. [CrossRef] [PubMed]

26. Guo, X.-F.; Yang, B.; Tang, J.; Jiang, J.-J.; Li, D. Apple and pear consumption and type 2 diabetes mellitus risk: A meta-analysis of prospective cohort studies. Food Funct. 2017, 8, 927-934. [CrossRef]

27. Bondonno, N.P.; Davey, R.J.; Murray, K.; Radavelli-Bagatini, S.; Bondonno, C.P.; Blekkenhorst, L.C.; Sim, M.; Magliano, D.J.; Daly, R.M.; Shaw, J.E.; et al. Associations between fruit intake and risk of diabetes in the AusDiab cohort. J. Clin. Endocrinol. Metab. 2021. [CrossRef]

28. Jia, X.; Xuan, L.; Dai, H.; Zhu, W.; Deng, C.; Wang, T.; Li, M.; Zhao, Z.; Xu, Y.; Lu, J.; et al. Fruit intake, genetic risk and type 2 diabetes: A population-based gene-diet interaction analysis. Eur. J. Nutr. 2021, 1-11. [CrossRef]

29. Lubransky, A.; Monro, J.; Mishra, S.; Yu, H.; Haszard, J.J.; Venn, B.J. Postprandial Glycaemic, Hormonal and Satiety Responses to Rice and Kiwifruit Preloads in Chinese Adults: A Randomised Controlled Crossover Trial. Nutrients 2018, 10, 1110. [CrossRef]

30. Zhu, R.; Fan, Z.; Dong, Y.; Liu, M.; Wang, L.; Pan, H. Postprandial glycaemic responses of dried fruit-containing meals in healthy adults: Results from a randomised trial. Nutrients 2018, 10, 694. [CrossRef]

31. Jenkins, D.J.A.; Srichaikul, K.; Kendall, C.W.C.; Sievenpiper, J.L.; Abdulnour, S.; Mirrahimi, A.; Meneses, C.; Nishi, S.; He, X.; Lee, S.; et al. The relation of low glycaemic index fruit consumption to glycaemic control and risk factors for coronary heart disease in type 2 diabetes. Diabetologia 2011, 54, 271-279. [CrossRef]

32. Alperet, D.J.; Butler, L.M.; Koh, W.-P.; Yuan, J.-M.; Van Dam, R.M. Influence of temperate, subtropical, and tropical fruit consumption on risk of type 2 diabetes in an Asian population. Am. J. Clin. Nutr. 2017, 105, 736-745. [CrossRef]

33. Georg, M.G.; Kristensen, M.; Belza, A.; Knudsen, J.C.; Astrup, A. Acute Effect of Alginate-Based Preload on Satiety Feelings, Energy Intake, and Gastric Emptying Rate in Healthy Subjects. Obesity 2012, 20, 1851-1858. [CrossRef]

34. Chang, U.J.; Hong, Y.H.; Suh, H.J.; Jung, E.Y. Lowering the energy density of parboiled rice by adding water-rich vegetables can decrease total energy intake in a parboiled rice-based diet without reducing satiety on healthy women. Appetite 2010, 55, 338-342. [CrossRef]

35. Hervik, A.K.; Svihus, B. The Role of Fiber in Energy Balance. J. Nutr. Metab. 2019, 2019, 4983657. [CrossRef]

36. Blundell, J.; De Graaf, C.; Hulshof, T.; Jebb, S.; Livingstone, B.; Lluch, A.; Mela, D.; Salah, S.; Schuring, E.; Van Der Knaap, H.; et al. Appetite control: Methodological aspects of the evaluation of foods. Obes. Rev. 2010, 11, 251-270. [CrossRef]

37. Hyson, D.A. A Comprehensive Review of Apples and Apple Components and Their Relationship to Human Health. Adv. Nutr. 2011, 2, 408-420. [CrossRef] [PubMed]

38. Babu, P.V.A.; Liu, D.; Gilbert, E.R. Recent advances in understanding the anti-diabetic actions of dietary flavonoids. J. Nutr. Biochem. 2013, 24, 1777-1789. [CrossRef] 
39. Cao, H.; Ou, J.; Chen, L.; Zhang, Y.; Szkudelski, T.; Delmas, D.; Daglia, M.; Xiao, J. Dietary polyphenols and type 2 diabetes: Human Study and Clinical Trial. Crit. Rev. Food Sci. Nutr. 2019, 59, 3371-3379. [CrossRef] [PubMed]

40. Liu, Y.; Heying, E.; Tanumihardjo, S.A. History, Global Distribution, and Nutritional Importance of Citrus Fruits. Compr. Rev. Food Sci. Food Saf. 2012, 11, 530-545. [CrossRef]

41. Visvanathan, R.; Williamson, G. Effect of citrus fruit and juice consumption on risk of developing type 2 diabetes: Evidence on polyphenols from epidemiological and intervention studies. Trends Food Sci. Technol. 2021, 115, 133-146. [CrossRef]

42. Sievenpiper, J.L. Fructose: Back to the future? Am. J. Clin. Nutr. 2017, 106, 439-442. [CrossRef]

43. Choo, V.L.; Viguiliouk, E.; Mejia, S.B.; Cozma, A.I.; Khan, T.A.; Ha, V.; Wolever, T.M.S.; Leiter, L.A.; Vuksan, V.; Kendall, C.W.C.; et al. Food sources of fructose-containing sugars and glycaemic control: Systematic review and meta-analysis of controlled intervention studies. Br. Med. J. 2018, 363, k4644. [CrossRef] [PubMed]

44. Cozma, A.I.; Sievenpiper, J.L.; de Souza, R.; Chiavaroli, L.; Ha, V.; Wang, D.D.; Mirrahimi, A.; Yu, M.E.; Carleton, A.J.; Di Buono, M.; et al. Effect of Fructose on Glycemic Control in Diabetes: A systematic review and meta-analysis of controlled feeding trials. Diabetes Care 2012, 35, 1611-1620. [CrossRef] [PubMed]

45. Ter Horst, K.W.; Schene, M.R.; Holman, R.; Romijn, J.A.; Serlie, M.J. Effect of fructose consumption on insulin sensitivity in nondiabetic subjects: A systematic review and meta-analysis of diet-intervention trials. Am. J. Clin. Nutr. 2016, 104, 1562-1576. [CrossRef]

46. Sievenpiper, J.L.; Chiavaroli, L.; de Souza, R.; Mirrahimi, A.; Cozma, A.I.; Ha, V.; Wang, D.D.; Yu, M.E.; Carleton, A.J.; Beyene, J.; et al 'Catalytic' doses of fructose may benefit glycaemic control without harming cardiometabolic risk factors: A small meta-analysis of randomised controlled feeding trials. Br. J. Nutr. 2012, 108, 418-423. [CrossRef]

47. Moore, M.C.; Cherrington, A.D.; Mann, S.L.; Davis, S.N. Acute fructose administration decreases the glycemic response to an oral glucose tolerance test in normal adults. J. Clin. Endocr. Metab. 2000, 85, 4515-4519. [CrossRef]

48. Moore, M.C.; Davis, S.N.; Mann, S.L.; Cherrington, A.D. Acute fructose administration improves oral glucose tolerance in adults with type 2 diabetes. Diabetes Care 2001, 24, 1882-1887. [CrossRef]

49. Vaisman, N.; Niv, E.; Izkhakov, Y. Catalytic amounts of fructose may improve glucose tolerance in subjects with uncontrolled non-insulin-dependent diabetes. Clin. Nutr. 2006, 25, 617-621. [CrossRef] [PubMed]

50. Wu, C.; Liu, P.; Yuan, Z. Fruit and vegetable intake is inversely associated with type 2 diabetes in Chinese women: Results from the China Health and Nutrition Survey. Int. J. Food Sci. Nutr. 2021, 72, 208-218. [CrossRef]

51. Mishra, S.; Edwards, H.; Hedderley, D.; Podd, J.; Monro, J. Kiwifruit Non-Sugar Components Reduce Glycaemic Response to Co-Ingested Cereal in Humans. Nutrients 2017, 9, 1195. [CrossRef] [PubMed]

52. Petersen, K.F.; Laurent, D.; Yu, C.; Cline, G.W.; Shulman, G.I. Stimulating effects of low-dose fructose on insulin-stimulated hepatic glycogen synthesis in humans. Diabetes 2001, 50, 1263-1268. [CrossRef] [PubMed]

53. Geidl-Flueck, B.; Gerber, P.A. Insights into the Hexose Liver Metabolism—Glucose versus Fructose. Nutrients 2017, 9, 1026. [CrossRef] [PubMed]

54. Raphaelli, C.D.O.; Pereira, E.D.S.; Camargo, T.M.; Vinholes, J.; Rombaldi, C.V.; Vizzotto, M.; Nora, L. Apple Phenolic Extracts Strongly Inhibit $\alpha$-Glucosidase Activity. Plant Foods Hum. Nutr. 2019, 74, 430-435. [CrossRef] [PubMed]

55. Hanhineva, K.; Törrönen, R.; Bondia-Pons, I.; Pekkinen, J.; Kolehmainen, M.; Mykkänen, H.; Poutanen, K. Impact of Dietary Polyphenols on Carbohydrate Metabolism. Int. J. Mol. Sci. 2010, 11, 1365-1402. [CrossRef]

56. Yu, K.; Ke, M.-Y.; Li, W.-H.; Zhang, S.-Q.; Fang, X.-C. The impact of soluble dietary fibre on gastric emptying, postprandial blood glucose and insulin in patients with type 2 diabetes. Asia Pac. J. Clin. Nutr. 2014, 23, 210-218.

57. Zhao, W.; Wang, L.; Fan, Z.; Lu, J.; Zhu, R.; Wu, Y.; Lu, X. Co-ingested vinegar-soaked or preloaded dried apple mitigated acute postprandial glycemia of rice meal in healthy subjects under equicarbohydrate conditions. Nutr. Res. 2020, 83, 108-118 [CrossRef]

58. Kasuya, N.; Okuyama, M.; Yoshida, K.; Sunabori, S.; Suganuma, H.; Murata, I.; Inoue, Y.; Kanamoto, I. Prior or Concomitant Drinking of Vegetable Juice with a Meal Attenuates Postprandial Blood Glucose Elevation in Healthy Young Adults. Food Nutr. Sci. 2016, 07, 797-806. [CrossRef]

59. Saito, Y.; Nitta, A.; Imai, S.; Kajiyama, S.; Miyawaki, T.; Ozasa, N.; Kajiyama, S.; Hashimoto, Y.; Fukui, M. Tomato juice preload has a significant impact on postprandial glucose concentration in healthy women: A randomized cross-over trial. Asia Pac. J. Clin. Nutr. 2020, 29, 491-497.

60. Zhao, W.; Zhou, Y.; Yuan, Y.; Fan, Z.; Wu, Y.; Liu, A.; Lu, X. Potato Preload Mitigated Postprandial Glycemic Excursion in Healthy Subjects: An Acute Randomized Trial. Nutrients 2020, 12, 2759. [CrossRef]

61. Sonoki, K.; Iwase, M.; Takata, Y.; Nakamoto, T.; Masaki, C.; Hosokawa, R.; Murakami, S.; Chiwata, K.; Inoue, H. Effects of thirty-times chewing per bite on secretion of glucagon-like peptide-1 in healthy volunteers and type 2 diabetic patients. Endocr. J. 2013, 60, 311-319. [CrossRef]

62. Kokkinos, A.; Le Roux, C.; Alexiadou, K.; Tentolouris, N.; Vincent, R.; Kyriaki, D.; Perrea, D.; Ghatei, M.A.; Bloom, S.R.; Katsilambros, N. Eating Slowly Increases the Postprandial Response of the Anorexigenic Gut Hormones, Peptide YY and Glucagon-Like Peptide-1. J. Clin. Endocrinol. Metab. 2010, 95, 333-337. [CrossRef] [PubMed]

63. Hakim, B.N.A.; Yahya, H.M.; Shahar, S.; Manaf, Z.A.; Damanhuri, H. Effect of Sequence of Fruit Intake in a Meal on Satiety. Int. J. Environ. Res. Public Health. 2019, 16, 4464. [CrossRef] [PubMed] 